\title{
Kajian Teori Breaking Bad Habit Sebagai Solusi Memutus Kebiasaan Negatif Siswa Dalam Pembelajaran
}

\author{
Teguh Hadi Wibowo \\ Universitas Muhammadiyah Lamongan, Indonesia
}

\begin{abstract}
This article was an assessment of breaking bad habits theory offered by E.R. Guthrie by providing reinforcement from an Islamic teaching point of view so that it could be used as a solution to break bad habits of students in a lesson. There are three methods offered by E.R. Guthrie in breaking bad habits: First, the threshold method. This method is in accordance with the four stages of break the habit of drinking khamr found in Qur'an. Second, the fatigue method. This method is in accordance with the command to be patient in telling family members to pray as stated in Thāha verse 132. Third, the incompatible response method. This method is in accordance with Islamic views, one of which is found in surah al-Burûj verses 10-11. In addition to the above three methods, in the view of Islam, there are elements in a lesson that are no less important, namely the environmental elements, that good or bad the character of an individual can be formed by the surrounding environment, as implied in the hadith of the Prophet Mohamed about the parable of a good friend such as musk oil traders and bad friends such as the blacksmith's fire blower.
\end{abstract}

Keywords: solution, bad habits, learning

\section{Pendahuluan}

Pada setiap situasi pembelajaran peserta didik tidak hanya belajar tentang materi pelajaran yang sedang diajarkan. Pada saat itu mereka juga belajar mengubah sikap, mengembangkan minat, dan membuat penyesuaian secara emosional maupun sosial (Purwanto, 2012, p.18). Artinya, selain belajar tentang materi pelajaran, peserta didik juga belajar bagaimana bersikap dan bagaimana membuat penyesuaian secara emosional maupun sosial.

Hal ini menurut Azhar Arsyad disebut sebagai pengalaman belajar. Pengalaman belajar adalah suatu proses yang sangat kompleks yang terjadi pada diri setiap orang sepanjang hidupnya. Proses itu terjadi karena adanya interaksi antara seseorang dengan lingkungannya (Arsyad, 2007, p.1). Interaksi dengan lingkungan ini mencakup lingkup yang lebih luas seperti keluarga, rumah, masyarakat, alam sekitar, sekolah, dll. 
Salah satu pertanda bahwa seseorang telah memiliki pengalaman belajar adalah adanya perubahan tingkah laku pada diri orang tersebut, yang disebabkan oleh terjadinya perubahan pada tingkat pengetahuan, keterampilan dan sikapnya (Arsyad, 2007, p.1). Perubahan pada tingkat pengetahuan, ketrampilan maupun sikap tersebut merupakan gejala internal berupa kecenderungan untuk merespon dengan cara yang relatif tetap terhadap objek, orang, peristiwa dan sebagainya, baik secara positif maupun negatif.

Perubahan yang terjadi melalui proses belajar ini bisa saja mengarah ke arah yang lebih baik namun bisa juga sebaliknya, ke arah yang lebih buruk (Baharuddin dan Wahyuni, 2010, p.14). Hal ini terjadi karena, selama ini, hasil belajar hanya diamati dari adanya perubahan dari tidak tahu menjadi tahu, dari tidak terampil menjadi terampil atau baru menyentuh domain kognitif.

Padahal, jauh-jauh hari, Ki Hadjar Dewantara menegaskan bahwa konsep pendidikan yang lebih menekankan pada akal semata, namun menegasikan akal budi guna mempertajam kepekaan sosial, merupakan sebuah hal yang harus ditinggalkan karena konsep pendidikan ini merusak kehidupan dan karakter bangsa di negeri ini (Yamin, 2009, p.172). Artinya pendidikan yang hanya menyentuh domain kognitif tersebut harus segera ditinggalkan untuk menyelamatkan kehidupan dan karakter anakanak didik di masa depan.

Konsep Ki Hajar di atas sesuai dengan amanat undang-undang pendidikan nomor 20/2003 pasal 1 ayat 1, bahwa pendidikan adalah suatu usaha sadar dan terencana untuk mewujudkan suasana belajar dan proses pembelajaran agar peserta didik secara aktif mengembangkan potensi dirinya untuk memiliki kekuatan spiritual keagamaan, pengendalian diri, kepribadian, kecerdasan, akhlak mulia serta ketrampilan yang diperlukan dirinya, masyarakat, bangsa dan negara.

Jika ingin proses pembelajaran berhasil sesuai amanat undang-undang di atas, maka, keunikan karakteristik psikologis yang dimiliki oleh setiap peserta didik haruslah diketahui dan dipahami oleh setiap guru yang berperan sebagai pendidik dan pengajar di kelas. Pengetahuan tentang psikologi ini sangat diperlukan oleh guru, karena para guru akan menghadapi peserta didik yang memiliki keunikan karakteristik dari berbagai 
aspek psikologis yang berbeda antara peserta didik yang satu dengan peserta didik yang lainnya.

Berkaitan dengan hal di atas, banyak sekali pertanyaan yang sering kita dengar menyangkut proses pembelajaran yang hingga kini, masih, belum tuntas terjawab. Pertanyaan-pertanyaan tersebut berkisar pada permasalahan, antara lain, bagaimana seorang guru/pendidik dapat mengomunikasikan secara efektif dengan peserta didik yang mempertanyakan alasan, arti, dan relevansi dari pembelajaran. Kemudian, bagaimana cara terbaik untuk menyampaikan banyak sekali konsep pembelajaran kepada semua peserta didik, yang tentu memiliki karakteristik yang berbeda-beda, sehingga mereka dapat tetap mengingat informasi yang didapatnya dan menggunakannya. Hingga pada satu pertanyaan klasik tentang bagaimanakah proses pembelajaran itu dapat berjalan dengan lancar sedangkan terdapat beberapa peserta didik yang memiliki kebiasaan negatif, sehingga mempersulit dan menghambat kemajuan belajar sendiri, teman-teman, dan bahkan menggangu proses pembelajaran yang sedang berlangsung.

Pertanyaan-pertanyaan tersebut cukup beralasan, karena berbagai fakta di lapangan menunjukkan fenomena yang cukup memprihatinkan. Pertama, kebanyakan guru/pendidik di sekolah tidak dapat membuat hubungan antara apa yang mereka ajarkan dan bagaimana pengetahuan tersebut akan dapat diaplikasikan oleh peserta didik, hal ini jika dibiarkan berlarut-larut akan menghilangkan motivasi siswa. Kedua, peserta didik menghadapi kesulitan saat mereka diajar dengan metode tradisional, terutama pada banyaknya konsep yang tidak mungkin semuanya diceramahkan oleh seorang guru/pendidik. Hal ini dapat menurunkan minat belajar siswa. Ketiga, kebanyakan guru/pendidik kurang mengenal dan memahami karakter (perilaku, kepribadian, sikap) setiap peserta didiknya. Berbeda dengan dua permasalahan sebelumnya, permasalahan yang ketiga, jika dibiarkan berlarut-larut akan merusak kehidupan dan karakter bangsa di negeri ini, dampaknya, kita juga yang akan dipaksa menanggung akibatnya.

Langkah untuk menghentikan kebiasaan-kebiasaan peserta didik yang inaproprite (tidak sesuai) tersebut, tidak lain adalah dengan memutus kebiasaan- 
kebiasaan itu. Untuk memutus kebiasaan-kebiasaan tersebut perlu memutus pula hubungan antara asosiasi yang memunculkan stimuli dan respons. Sederhananya, yang harus kita lakukan untuk memutus kebiasaan adalah mencari petunjuk yang memicu kebiasaan buruk kemudian melakukan respon lain saat petunjuk itu muncul.

Mengingat betapa berbahayanya jika kebiasaan inaproprite peserta didik terlalu lama dibiarkan, maka peneliti terpicu untuk melakukan suatu kajian terhadap teori memutus kebiasaan negatif yang ditawarkan oleh Edwin Ray Guthrie dengan memberikan penguat dari sudut pandang ajaran Islam agar dapat digunakan sebagai solusi memutus kebiasaan buruk siswa dalam pembelajaran.

\section{Pembahasan}

\section{Pengertian Bad Habit}

Bad habit, secara etimologis, terdiri dari dua kata bad dan habit. Kata bad berarti buruk atau negatif. Sedangkan habit sepadan dengan العَاََّة dalam bahasa Arab dan kebiasaan dalam bahasa Indonesia. Habit dalam Cambridge Dictionary diartikan "Something that you do often and regularly, sometimes without knowing that you are doing it". Menurut definisi tersebut bahwa habit atau kebiasaan adalah sesuatu yang dilakukan secara sering dan teratur, bahkan terkadang secara tidak sadar ternyata sedang melakukannya.

Sedangkan dalam KBBI kebiasaan ialah pola untuk melakukan tanggapan terhadap situasi tertentu yang dipelajari oleh seorang individu dan yang dilakukannya secara berulang untuk hal yang sama. Artinya, kebiasaan adalah hal yang sama yang dipelajari oleh seseorang dan dilakukan secara berulang-ulang.

Kebiasaan menurut Muhammad Sayid adalah pengulangan sesuatu secara terus-menerus atau dalam sebagian besar waktu dengan cara yang sama dan tanpa pertimbangan akal, atau sesuatu yang tertanam di dalam jiwa dari hal-hal yang berulang kali terjadi (Az-Za'balawi, 2006, p.347).

Berdasarkan beberapa definisi di atas, dapat peneliti simpulkan bahwa habit atau kebiasaan adalah serangkaian perbuatan seseorang yang dilakukan secara 
berulang-ulang dalam hal yang sama dan berlangsung secara otomatis tanpa proses berpikir lagi. Maka bad habit dapat dimaknai sebagai serangkaian perbuatan buruk seseorang yang dilakukan secara berulang-ulang dan berlangsung secara otomatis tanpa proses berpikir lagi.

\section{Karakteristik Bad Habit}

Berdasarkan pengertian di atas ditemukan dua karakteristik bad habit sebagai berikut: Pertama, suatu perbuatan buruk disebut bad habit jika perbuatan tersebut dilakukan secara berulang-ulang. Artinya perbuatan atau tindakan buruk tersebut konsisten dilakukan secara terus menerus. Apabila perbuatan buruk tersebut hanya dilakukan sekali atau kadang-kadang, maka perbuatan buruk tersebut tidak dapat disebut sebagai bad habit.

Kedua, suatu perbuatan buruk disebut bad habit jika perbuatan dilakukan secara otomatis tanpa proses berpikir lagi. Hal ini terjadi karena sudah terbentuk suatu pola di level pikiran bawah sadar. Artinya kebiasaan buruk seseorang akan selalu terekam dalam alam bawah sadarnya. Sehingga tanpa disadari, kebiasaan tersebut akan sulit untuk dirubah.

\section{Macam-Macam Bad Habit}

Berdasarkan karakteristik di atas ditemukan bermacam bentuk bad habit di antaranya sebagai berikut:

a. Tidak displin. Termasuk kebiasaan tidak disiplin yaitu membuang sampah sembarangan, sering terlambat, bolos dan sebagainya.

b. Merokok. Sudah umum diketahui bahwa kebiasaan merokok mempunyai banyak dampak buruk bagi kesehatan baik bagi perokok aktif maupun bagi perokok pasif.

c. Berkata kasar. Kebiasaan berkata kasar itu dapat membuat sakit hati orang lain yang mendengarkannya. Termasuk dalam kata kasar adalah sumpah serapah dan makian. Intinya, perbuatan buruk apapun dapat dikategorikan sebagai bad habit jika perbuatan tersebut memenuhi karakteristik dilakukan secara berulang-ulang dan dilakukan secara otomatis tanpa proses berpikir lagi. 


\section{Faktor pembentuk Bad Habit}

Terdapat dua faktor pembentuk bad habit yakni imitasi dan pembiasaan. Adapun penjelasannya sebagaimana berikut:

a. Imitasi (Peniruan)

Kebanyakan perilaku manusia dan kebiasaannya merupakan hasil tiruan dari orang yang ada di sekelilingnya, termasuk juga kebiasaan buruk (bad habit). Proses pembentukan kebiasaan tersebut bisa berjalan dengan sempurna melalui proses imitasi (peniruan). Hal ini terealisasi ketika seseorang meniru orang lain dalam mengerjakan sesuatu maupun melafalkan suatu kata. Pendapat tersebut dikuatkan oleh al-Attas dalam (Daud, 2003, p.263) bahwa imitasi tidak hanya sebatas proses peniruan buta yang memandulkan kemampuan rasional dan intelektual seseorang.

b. Pembiasaan

Selain peniruan, kebiasaan buruk manusia merupakan hasil dari pembiasaan yang dilakukan. Seseorang dikatakan melakukan pembiasaan jika suatu perbuatan dilakukan secara berulang-ulang hingga tanpa proses berpikir lagi atau sudah dalam keadaan terbiasa (Rusuli, 2014, p.48).

\section{Konsep Breaking Bad Habits}

Riset awal tentang proses belajar dilakukan melalui perspektif perilaku dimana tingkah laku (behavior) yang dapat diamati sangat ditekankan dalam proses belajar. Menurut perspektif aliran behaviorisme, belajar pada hakikatnya adalah pembentukan asosiasi antara kesan yang ditangkap panca indera dengan kecenderungan untuk bertindak atau hubungan antara Stimulus dan Respons (S-R). Oleh karena itu teori ini juga dinamakan teori Stimulus-Respons. Belajar adalah upaya untuk membentuk hubungan stimulus dan respon sebanyak-banyaknya (Sanjaya, 2013, p.237).

Belajar diartikan sebagai suatu perubahan tingkah laku yang dapat diamati secara langsung, yang terjadi melalui hubungan stimulus-stimulus dan respon-respon menurut prinsip-prinsip mekanistik (Dahar, 1988, p.24). Sederhananya, seseorang 
dianggap telah belajar sesuatu jika sudah mampu menunjukkan perubahan tingkah lakunya.

Sigit Sanyata dalam (Rusuli, 2014, p.41) menegaskan bahwa perilaku individu merupakan hasil belajar yang dapat diubah dengan memanipulasi dan mengkreasikan kondisi-kondisi belajar dan didukung dengan berbagai penguatan (reinforcement) untuk mempertahankan perilaku atau hasil belajar yang dikehendaki. Menurut konsep ini yang terpenting dalam belajar adalah input yang berupa stimulus dan output yang berupa respon. Artinya seseorang dikatakan berhasil dalam belajar apabila orang tersebut sudah mampu mengasosiasikan stimulus-stimulus dan responrespon yang diberi reinforcement dengan memberikan respon yang benar.

Sedikit berbeda dengan konsep di atas, Edwin R. Guthrie (1886-1959) berasumsi bahwa terjadinya peristiwa belajar itu berdasarkan kedekatan hubungan antara stimulus dengan respon yang relevan. Terdapat prinsip kontiguitas (contiguity), di dalamnya, yang berarti kedekatan antara stimulus dengan respon. (Rusuli, 2014, p.45).

Oleh karena itu, menurut E. R. Guthrie, peningkatan hasil belajar itu bukanlah hasil berbagai respon yang kompleks terhadap stimulus-stimulus yang ada, melainkan karena dekatnya asosiasi antara stimulus dengan respon yang diperlukan. Misalnya, seorang siswa diberi stimulus berupa penjumlahan $2+2$, maka siswa akan merespon dengan 4. Ini menunjukkan adanya kedekatan antara stimulus dengan respon. Jadi dalam proses belajar menurut model ini, terdapat kaitan yang dekat antara stimulus dan respon.

Salah satu eksperimen yang dilakukan oleh Guthrie untuk mendukung teori kontiguitas adalah percobaannya pada tahun 1946. Guthrie melakukan suatu studi kolaboratif dengan George P. Horton dimana melibatkan perilaku kucing di dalam kotak Puzzle. Eksperimen Guthrie-Horton ini menggambarkan konsep pelajaran assosiatif. Mereka menggunakan kucing sebagai objek penelitian, yang dimasukkan ke dalam suatu kotak kaca yang diberi papan agar mereka bisa mengawasi pergerakan kucing itu. Kotak dibangun sedemikian rupa sehingga kucing bisa membuka pintu dengan menyentuh tombol. Selain itu kotak tersebut juga dilengkapi 
dengan alat yang dapat merekam gerakan-gerakan kucing dalam kotak (Sanjaya, 2013, p.240).

Pada percobaan pertama dibutuhkan waktu 15 menit untuk kucing tersebut dapat menyentuh tombol itu. Percobaan yang kedua, kucing mempunyai kecenderungan untuk mengulang perilaku pertamanya. Penelitian menunjukkan bahwa kucing selalu mengulangi urutan pergerakan yang sama jika dihubungkan dengan yang sebelum dilepas dari kotak itu. Ini menunjukkan suatu contoh dari pengulangan perilaku. Eksperimen Guthrie-Horton menggambarkan kepada kita semua untuk mengasumsikan perbandingan hewan untuk belajar dari suatu asosiasi (hubungan) antar suatu stimulus dan tindakan sekedar tingkah laku dari pengalaman terdahulu.

Hasil percobaan tersebut dikuatkan sendiri oleh Guthrie bahwa "A combination of stimuli which has accompanied a movement will on its recurrence tend tobe followed by that movement" (Guthrie, 1952, p.13). Menurut pendapat Guthrie tersebut, bahwa gabungan atau kombinasi suatu kelas stimuli yang menyertai atau mengikuti suatu gerakan tertentu, maka ada kecenderungan bahwa gerakan itu akan diulangi lagi pada stimuli yang sama.

Guthrie mengemukakan bahwa tingkah laku manusia itu secara keseluruhan dapat dipandang sebagai deretan-deretan tingkah laku yang terdiri dari unit-unit. Unit-unit tingkah laku ini merupakan reaksi atau respons dari perangsang atau stimulus sebelumnya, dan kemudian unit tersebut menjadi pula stimulus yang kemudian menimbulkan respons bagi unit tingkah laku yang berikutnya. Demikianlah seterusnya sehingga merupakan deretan-deretan unit tingkah laku yang terusmenerus. Jadi pada proses conditioning ini pada umumnya terjadi proses asosiasi antara unit-unit tingkah laku satu sama lain yang berurutan. Ulangan yang berkalikali memperkuat asosiasi yang terdapat antara unit tingkah laku yang satu dengan unit tingkah laku yang berikutnya (Syah, 2010, p.99).

Tingkah laku atau kebiasaan dalam konsep Guthrie didefinisikan sebagai sebuah respon yang diasosiasikan dengan beberapa stimuli yang berbeda. Lebih besar jumlah asosiasi, lebih kuat kebiasaan yang muncul karena "ditandai" atas 
beberapa tindakan-tindakan (Baharuddin dan Wahyuni, 2010, p.79-80). Dengan kata lain, Semakin banyak stimuli yang menimbulkan respon, maka akan semakin kuat kebiasaan. Misalnya, merokok adalah salah satu contoh sebuah kebiasaan kuat karena banyak diarahkan oleh beberapa stimuli yang berbeda, seperti sehabis makan, tersedia kopi, sambil membaca koran, dan lain sebagainya.

Untuk menghentikan kebiasaan yang inaproprite (tidak sesuai), maka kebiasaan itu perlu diputus. Untuk itu, perlu memutus pula hubungan antara asosiasi yang memunculkan stimuli dan respons (Baharuddin dan Wahyuni, 2010, p.80). Sederhananya, yang harus kita lakukan untuk memutus kebiasaan adalah mencari petunjuk yang memicu kebiasaan buruk kemudian melakukan respon lain saat petunjuk itu muncul. Ada tiga metode yang ditawarkan oleh Guthrie untuk memutuskan kebiasaan, yaitu:

1. Metode Ambang Batas (threshold method): dengan memperkenalkan stimulus lemah yang tidak menimbulkan respon dan kemudian pelan-pelan menaikkan intensitas stimulus itu, tetapi selalu berhati-hati agar ia tetap berada di bawah “ambang batas" respon. Contoh memasang pelana kuda: mulai dengan selimut yang ringan, kemudian yang lebih berat, baru kemudian pelana kuda.

2. Metode Kelelahan (fatigue method): dengan mendorong stimulus secara terus menerus sampai respon yang diberikan berhenti atau tidak ada respon lagi. Contoh: penjinakan dimana pelana dilempar ke punggung kuda kemudian penunggangnya menaikinya dan berusaha mengendarai kuda itu sampai kuda itu menyerah. Contoh lain: Umpamakan seorang anak yang keasyikan memakan kepala korek api. Supaya kebiasaan itu berhenti, maka anak itu disuruh menghabiskan kepala korek api satu pak sehingga menjadi bosan.

3. Metode Respon yang Tidak Sesuai (incompatible respons method): stimuli untuk respon yang tidak diinginkan disajikan bersama stimuli lain yang menghasilkan respon yang tidak sesuai dengan respon yang tidak diinginkan tersebut. Contoh seorang anak mendapat hadiah boneka panda namun reaksi pertamanya takut dan menghindar. Sebaliknya ibu si anak memberikan rasa kehangatan dan kenyamanan pada diri si anak. Dengan menggunakan metode 
respon yang tak kompatibel anda akan memasangkan ibu dan boneka panda diharapkan ibu akan menjadi stimulus dominan. Jika ibu menjadi stimulus dominan, reaksi anak terhadap kombinasi ibu-boneka itu akan berupa relaksasi. Setelah reaksi relaksasi muncul ketika ada boneka panda, maka boneka itu dapat dihadirkan sendirian dan akan muncul relaksasi dalam diri anak. Contoh lain: Seorang anak takut kepada kucing. Sambil memperlihatkan kucing pada anak tersebut, berilah anak itu makanan yang disukainya supaya anak itu merasa senang. Lakukanlah usaha ini berkali-kali, akhirnya anak tersebut tidak takut lagi kepada kucing (Guthrie, 1934, p. 450-460).

Berikut tabel tiga metode breaking bad habits yang ditawarkan oleh E. R. Guthrie di atas:

\section{Tabel 1}

Konsep Breaking bad habits E.R. Guthrie

\begin{tabular}{|c|c|c|}
\hline Metode & Karakteristik & Contoh \\
\hline $\begin{array}{l}\text { Metode Threshold } \\
\text { (Ambang Batas) }\end{array}$ & $\begin{array}{l}\text { Mengenalkan stimuli } \\
\text { dengan kekuatan yang } \\
\text { lemah. Secara perlahan } \\
\text { meningkatkan kekuatan } \\
\text { stimuli, tetapi menjaganya } \\
\text { dibawah respons batas } \\
\text { minimal. }\end{array}$ & $\begin{array}{l}\text { Memasang pelana kuda: } \\
\text { mulai dengan selimut } \\
\text { yang ringan, kemudian } \\
\text { selimut yang lebih berat, } \\
\text { baru kemudian pelana } \\
\text { kuda. }\end{array}$ \\
\hline $\begin{array}{l}\text { Metode fatigue } \\
\text { (Keletihan) }\end{array}$ & $\begin{array}{l}\text { Mengeluarkan semua } \\
\text { respons dalam } \\
\text { menghadirkan stimuli. }\end{array}$ & $\begin{array}{l}\text { Melemparkan pelana } \\
\text { diatas kuda dan menaiki } \\
\text { kuda sampai kuda } \\
\text { meringkik, menendang, } \\
\text { dan berusaha sekuat } \\
\text { tenaga untuk melempar } \\
\text { orang yang menaikinya. }\end{array}$ \\
\hline
\end{tabular}




\begin{tabular}{l|l|l}
\hline & & (joki) : pelana dan joki \\
menjadi stimulus untuk \\
berjalan dan berlari \\
dengan tenang. \\
Respons (Respons
\end{tabular}

\section{Konsep Breaking Bad Habits dalam Pandangan Islam}

Terdapat kesesuaian antara pandangan Islam dengan metode-metode yang digunakan dalam konsep breaking bad habits untuk memutuskan kebiasaan yang dianggap tidak sesuai (inaproprite), kesesuaian tersebut terdapat pada, antara lain: pertama, metode ambang batas (threshold method), metode ini dilakukan dengan cara memperkenalkan stimulus lemah yang tidak menimbulkan respon dan kemudian pelan-pelan menaikkan intensitas stimulus itu. Metode ini sesuai dengan pandangan Islam, salah satunya, tentang tahapan memutus kebiasaan meminum khamr, setidaknya ada empat tahapan yang dilalui, dari stimulus lemah dan kemudian pelanpelan menaikkan intensitas stimulus itu, sampai terbentuknya kebiasaan baru. Empat tahap tersebut dapat diketahui melalui pengkajian terhadap Asbab An-Nuzul ayat-ayat yang berkaitan dengan khamr. 
Tahap pertama terdapat pada surah an-Nahl ayat 67 (lihat Kementerian Agama RI, 2010, p.274), pada ayat tersebut sama sekali tidak disinggung tentang keharaman khamr, hal ini menandakan bahwa pada saat awal Islam, khamr bukanlah minuman yang haram untuk dikonsumsi dan bukan dianggap kebiasaan buruk. Tahap kedua terdapat pada surah Al-Baqarah ayat 219 (lihat Kementerian Agama RI, 2010, p.34), pada ayat tersebut masih belum terdapat redaksi diharamkan khamr, hanya saja sudah muncul redaksi berdosa besar (Mahalli, 2002, p.343). Artinya pada tahapan pertama dan kedua di atas khamr masih dikonsumsi secara massif dan belum menjadi hal yang dianggap kebiasaan buruk jika dikonsumsi di depan umum.

Tahap ketiga terdapat pada surah an-Nisa ayat 43 (lihat Kementerian Agama RI, 2010, p.85), pada ayat tersebut sudah terdapat redaksi diharamkan khamr, tetapi baru sebatas ketika dalam keadaan sholat, agar apa yang dibaca di dalam sholat mampu dipahami, namun ketika sholat telah ditunaikan masih belum ada redaksi pengharamannya (Mahalli, 2002, p.343). Maksudnya pada tahapan ini khamr masih dikonsumsi secara massif namun apabila akan dilaksanakan sholat maka meminum khamr sudah diharamkan.

Tahap keempat sekaligus tahap terakhir terdapat pada surah al-Maidah ayat 9091 (lihat Kementerian Agama RI, 2010, p.123), pada ayat tersebut sudah sangat jelas redaksi diharamkannya khamr, pada ayat tersebut khamr disandingkan dengan berjudi, berkorban untuk berhala, berundi nasib dengan panah. Ayat tersebut merupakan akhir dari tahap pengharaman khamr. Setelah ayat tersebut turun khamr menjadi haram. Imam Al-Qurthubi menyebutkan bahwa sampai-sampai sebagian umat Muslim mengatakan bahwa Allah Swt tidak pernah mengharamkan sesuatu yang sangat dahsyat sebelumnya kecuali khamr (Al-Qurthubi, 2008, p.683).

Empat tahapan memutus kebiasaan meminum khamr di atas, sesuai dengan metode ambang batas (threshold method) dalam konsep breaking bad habits E.R. Guthrie, empat tahapan tersebut dimulai dari stimulus lemah yaitu dengan tidak terdapatnya redaksi keharaman khamr, kemudian pelan-pelan menaikkan intensitas stimulus itu, sehingga pada tahapan terakhir redaksi diharamkannya khamr sudah 
jelas, bahkan pada tahapan terakhir, keharaman khamr disandingkan dengan berjudi, berkorban untuk berhala, berundi nasib dengan panah.

Kedua, metode kelelahan (fatigue method) yaitu dengan mendorong stimulus secara terus menerus sampai respon yang diberikan berhenti atau tidak ada respon lagi. Metode ini sesuai dengan pandangan Islam, salah satunya, tentang perintah bersabar dalam menyuruh anggota keluarga untuk sholat. Perintah tersebut terdapat pada surat Thāhā ayat 132 (lihat Kementerian Agama RI, 2010, p.321). Ayat tersebut berisi perintah untuk sabar dalam menyuruh keluarga untuk sholat merupakan isyarat dari metode kelelahan (fatigue method) yang mengutamakan dorongan stimulus untuk sholat secara terus menerus, dengan bersabar, sampai tidak ada respon penolakan lagi (Andriyani, 2015, p.176).

Ketiga, metode respon yang tidak sesuai (incompatible respons method) yaitu stimuli untuk respon yang tidak diinginkan disajikan bersama stimuli lain yang menghasilkan respon yang tidak sesuai dengan respon yang tidak diinginkan tersebut. Metode ini sesuai dengan pandangan Islam, salah satunya terdapat pada surah al-Burûj ayat 10-11, dalam ayat tersebut pada mulanya disajikan stimuli awal (bagi yang mendatangkan cobaan kepada orang-orang yang mukmin laki-laki dan perempuan) bersamaan stimuli lain (mereka tidak bertaubat) maka akan menghasilkan respon yang tidak sesuai dengan respon yang tidak diinginkan tersebut (maka bagi mereka azab Jahannam dan bagi mereka azab (neraka) yang membakar) (lihat Kementerian Agama RI, 2010, p.590).

Selain ketiga metode di atas, dalam pandangan Islam, terdapat unsur dalam suatu pembelajaran yang tidak kalah penting yaitu unsur lingkungan, bahwa baik atau buruk karakter seorang individu bisa dibentuk oleh lingkungan sekitarnya, sebagaimana tersirat dalam hadits Nabi Muhammad SAW, beliau bersabda, yang artinya: Perumpamaan teman yang baik dan teman yang buruk seperti pedagang minyak kesturi dan peniup api tukang besi. Si pedagang minyak kesturi mungkin akan memberikannya kepadamu atau engkau membeli kepadanya atau setidaknya engkau dapat memperoleh bau harum darinya, tapi si peniup api tukang besi 
mungkin akan membuat badanmu atau pakaianmu terbakar atau mungkin engkau akan mendapat bau yang tidak sedap darinya (Al-'Asqolãnî, 1997, p.406).

Terdapat makna tersirat dari hadits Nabi di atas, bahwa unsur lingkungan sangat berpengaruh pada proses pembentukkan kepribadian seseorang. Jika lingkungannya baik, maka akan terbentuk kepribadian yang baik, dan jika lingkungannya buruk, maka akan terbentuk kepribadian yang buruk.

Menurut Sumardi Suryabrata, dalam psikologi pendidikan, bahwa unsur lingkungan dibagi menjadi dua, yaitu: lingkungan sosial dan lingkungan nonsosial. Termasuk dalam lingkungan sosial, yaitu: para guru, para staff administrasi, temanteman sekelas, termasuk juga, masyarakat, tetangga dan teman-teman sepermainan di sekitar tempat tinggal siswa tersebut (Suryabrata, 2010, p.67).

Sedangkan yang termasuk lingkungan non-sosial ialah gedung sekolah dan letaknya, alat-alat belajar, keadaan cuaca, waktu belajar yang digunakan siswa, termasuk juga, lingkungan alamiah, faktor instrumental dan faktor materi pelajaran (yang diajarkan ke siswa) (Suryabrata, 2010, p.67).

\section{Konsep Breaking Bad Habits dalam Pembelajaran}

Konsep breaking bad habits ini dapat diaplikasikan dalam dunia pembelajaran secara langsung dan dapat dilakukan oleh siapapun. Konsep ini dapat digunakan sebagai solusi untuk memutus kebiasaan negatif peserta didik pada saat proses pembelajaran berlangsung. Proses pembelajaran menurut konsep ini terjadi karena dekatnya asosiasi antara stimulus dengan respon yang diperlukan. Walaupun demikian, dalam proses pembelajaran tetap memerlukan reward, sedangkan hukuman akan lebih efektif apabila menyebabkan peserta didik itu mau belajar (Rusuli, 2014, p.45).

Diharapkan setelah kebiasaan negatif peserta didik terputus, akan tergantikan dengan kebiasaan-kebiasaan yang lebih positif sehingga proses pembelajaran berjalan dengan baik. Proses yang baik itu diharapkan dapat menjadi perubahan dalam kepribadian peserta didik yang kemudian dimanifestasikan sebagai pola-pola respon baru yang berbentuk ketrampilan, sikap, kebiasaan, pengetahuan dan kecakapan yang positif (Hanafiah dan Suhana, 2009, p.7). 


\section{Kesimpulan}

Ada tiga metode yang ditawarkan oleh E.R. Guthrie dalam memutus kebiasaan buruk: Pertama, Metode Ambang Batas (threshold method) yaitu dengan memperkenalkan stimulus lemah yang tidak menimbulkan respon dan kemudian pelanpelan menaikkan intensitas stimulus itu, tetapi selalu berhati-hati agar ia tetap berada di bawah "ambang batas" respon. Metode tersebut sesuai dengan empat tahapan memutus kebiasaan meminum khamr yang terdapat di dalam al-Qur'an.

Kedua, Metode Kelelahan (fatigue method) yaitu dengan mendorong stimulus secara terus menerus sampai respon yang diberikan berhenti atau tidak ada respon lagi. Metode ini sesuai dengan pandangan Islam, salah satunya, tentang perintah bersabar dalam menyuruh anggota keluarga untuk sholat. Perintah tersebut terdapat pada surat Thāhā ayat 132 .

Ketiga, Metode Respon yang Tidak Sesuai (incompatible respons method) yaitu stimuli untuk respon yang tidak diinginkan disajikan bersama stimuli lain yang menghasilkan respon yang tidak sesuai dengan respon yang tidak diinginkan tersebut. Metode ini sesuai dengan pandangan Islam, salah satunya terdapat pada surah al-Burûj ayat 10-11, dalam ayat tersebut pada mulanya disajikan stimuli awal (bagi yang mendatangkan cobaan kepada orang-orang yang mukmin laki-laki dan perempuan) bersamaan stimuli lain (mereka tidak bertaubat) maka akan menghasilkan respon yang tidak sesuai dengan respon yang tidak diinginkan tersebut (maka bagi mereka azab Jahannam dan bagi mereka azab (neraka) yang membakar).

Selain ketiga metode di atas, dalam pandangan Islam, terdapat unsur dalam suatu pembelajaran yang tidak kalah penting yaitu unsur lingkungan, bahwa baik atau buruk karakter seorang individu bisa dibentuk oleh lingkungan sekitarnya, sebagaimana tersirat dalam hadits Nabi Muhammad SAW tentang perumpamaan teman yang baik seperti pedagang minyak kesturi dan teman yang buruk seperti peniup api pandai besi. 


\section{Daftar Rujukan}

Al-‘Asqolãnî, Ibnu Hajar. 1997. Fathul Bãrî Syarhu Shahih Al-Bukhãrî. Jilid. 4. Beirut: Dar al-Kutub al- Ilmiyah.

Andriyani, Fera "Teori Belajar Behavioristik dan Pandangan Islam Tentang Behavioristik", SYAIKHUNA, Edisi 10, No. 2, Maret 2015.

Arsyad, Azhar. 2007. Media Pembelajaran. Jakarta: PT Raja Grafindo Persada.

Az-Za'balawi, Muhammad Sayid Muhammad. 2006. Pendidikan Remaja antara Islam dan Ilmu Jiwa. Jakarta: Gema Insani Press.

Baharuddin, H. dan Esa Nur Wahyuni. 2010. Teori Belajar dan Pembelajaran. Yogyakarta: Ar-Ruzz Media.

Dahar, Ratna Wilis. Teori-Teori Belajar. Jakarta: Depdikbud Dirjend Lembaga Tenaga Kependidikan. 1988.

Daud, Wan Mohd Nor Wan. 2003. Filsafat dan Praktik Pendidikan Islam Syed Naquib al-Attas,Terj. Hamid Fahmi. Bandung: Mizan.

Guthrie, E. R.. 1952. The Psychology of Learning: Revised Edition. Harper Bros: Massachusetts. . "Reward and punishment". Psychological Review, Vol 41 (5), Sep 1934.

Hanafiah, Nanang \& Cucu Suhana. 2009. Konsep Strategi Pembelajaran. Bandung: PT. Refika Aditama.

Kementerian Agama RI. 2010. Al-Qur'an Tajwid dan Terjemahnya. Jakarta: PT. Sygma Examedia Arkanleema.

Mahalli, A. Mudjab. 2002. Asbabun Nuzul (Studi Pendalaman Alquran). Jakarta: PT. Raja Grafindo Persada.

Nuriyah, Nunung. "Evaluasi Pembelajaran: Sebuah Kajian Teori", Jurnal Edueksos, Vol III No 1, Januari-Juni 2014.

Purwanto, M. Ngalim. 2012. Prinsip-Prinsip dan Teknik Evaluasi Pengajaran. Bandung: PT. Remaja Rosdakarya. 
Rusuli, Izzatur. Refleksi Teori Belajar Behavioristik Dalam Perspektif Islam, Jurnal Pencerahan, Vol. 8, Nomor 1, Juli - Desember 2014.

Sanjaya, Wina. 2008. Perencanaan dan Desain Sistem Pembelajaran. Jakarta: Kencana. 2013. Kurikulum dan Pembelajaran. Jakarta: Penerbit Kencana Prenada Media Grup.

Suryabrata, Sumardi. 2010. Psikologi Pendidikan. Jakarta: PT. Radja Grafindo Persada.

Suyono dan Hariyanto. 2011. Belajar dan Pembelajaran. Bandung: PT Remaja Rosdakarya.

Syah, Muhibbin. 2003. Psikologi belajar. Jakarta: Rajawali Press. . Psikologi Pendidikan. Bandung: PT Remaja Rosdakarya. 2010.

Yamin, Moh. 2009. Menggugat Pendidikan Indonesia (Belajar dari Paulo Freire dan Ki Hadjar Dewantara). Yogyakarta: Ar-Ruzz Media. 
Teguh Hadi Wibowo 